\title{
High-throughput transformation pipeline for a Brazilian japonica rice with bar gene selection
}

\author{
B. Dedicova $\cdot$ C. Bermudez $\cdot$ M. Prias $\cdot$ E. Zuniga $\cdot$ C. Brondani
}

Received: 24 March 2014 / Accepted: 27 November 2014 /Published online: 7 December 2014

(C) The Author(s) 2014. This article is published with open access at Springerlink.com

\begin{abstract}
The goal of this work was to establish a transformation pipeline for upland Curinga rice (Oryza sativa L. ssp. japonica) with bar gene selection employing bialaphos and phosphinothricin as selection agents. The following genes of interest: AtNCED3, Lsi1, GLU2, LEW2, PLD-alpha, DA1, TOR, AVP1, and Rubisco were cloned into the binary vector p7i2x-Ubi and were transferred into Agrobacterium strain EHA 105. Embryogenic calli derived from the mature embryos were transformed, and transgenic cells and shoots were selected on the medium supplemented with bialaphos or phosphinothricin (PPT) using a stepwise selection scheme. Molecular analyses were established using polymerase chain reaction and Southern blot for the bar gene and the NOS terminator. Overall, 273 putative transgenic plants were analyzed by Southern blot with 134 events identified. In total, 77 events had a single copy of the transgene integrated in the plant genome while 29 events had two copies. We tested backbone integration in 101 transgenic plants from all constructs and found 60 transgenic plants having no additional sequence integrated in the plant genome. The bar gene activity was evaluated by the chlorophenol red test and the leaf painting test using phosphinothricin with several transgenic plants. The majority of T0 plants carrying the single copy of transgene produced $\mathrm{T} 1$ seeds in the screen house.
\end{abstract}

Keywords Oryza sativa L · Upland rice ·

Agrobacterium-mediated transformation · Bar selection .

Backbone integration

Handling Editor: Burkhard Becker

B. Dedicova $(\varangle) \cdot$ C. Bermudez $\cdot$ M. Prias $\cdot$ E. Zuniga International Center for Tropical Agriculture A.A. 6713, Cali, Colombia

e-mail: beatadedicova@hotmail.com

C. Brondani

Embrapa Arroz e Feijão, Rodovia GO-462, Km 12 75.375-00,

Santo Antônio de Goiás, Goiás, Brazil

\section{Introduction}

Rice equates to life for thousands of millions people in Asia alone where more than 2000 million people obtain 60 to $70 \%$ of their calories from rice and its products (FAO 2013). In Latin America, rice is the most important food grain providing $27 \%$ of daily calorie intake overall, ranging from $8 \%$ in Central America to $47 \%$ in the Caribbean region (FAOSTAT 2012). Upland rice, known as aerobic rice, is grown in South America, Africa, and Asia (Fageria 2002). In the central part of Brazil (Cerrados), upland rice plays an important role in the cropping system whereby it is first grown after clearing land for pasture (Fageria 2010). The main limiting factors for adopting high-yielding rice varieties is drought and access to nitrogen in drought-prone rainfed rice environments (Fageria 2009). These two traits, drought tolerance and nitrogen-use efficiency, have been of high interest in past experimental research (Campbell et al. 1995; Umezawa et al. 2006; Serraj et al. 2008) and have been reviewed several times in recent years (Hadiarto and Tran L-S 2011; Lawlor 2013). Dozens of genes with different functions and modes of action have been identified (Shinozaki and Yamaguchi-Shinozaki 2007; Yang et al. 2010; Jeong et al. 2013) with several going through confined field testing (Deikman et al. 2011; Gaudin et al. 2013).

This study focused on following genes linked to plant stress resistance, plant growth, and yield: The AtNCED3 encodes the key enzyme in the abscisic acid (ABA) biosynthesis via overexpression of 9-cis-epoxycarotenoid dioxygenase in Arabidopsis (Iuchi et al. 2001). The Lsil gene (Low silicon rice 1) encodes the Si transporter from the aquaporin gene family, is expressed in rice roots (Ma et al. 2006), and is downregulated during dehydration stress by ABA (Yamaji and Ma 2007). The AtCEsA8/IRX1 gene from the Lew2 Arabidopsis mutants (Chen et al. 2005) is one of ten genes essential for the cellulose synthase complex in the secondary cell walls (Taylor 2008). The phospholipase $D \alpha 1$ $(P L D \alpha 1)$ gene is involved in the stress response through 
stomata closure directed by the ABA effect (Mishra et al. 2006; Uraji et al. 2012). Expression of the AtTOR kinase (target of rapamycin) influences seed and plant growth and controls resistance to osmotic stress (Deprost et al. 2007). Disruption of the TOR activity can lead to premature arrest of endosperm and embryo development (Menand et al. 2002). Another gene controlling seed and organ size is the $D A 1$ gene, which encodes the ubiquitin receptor that controls the cell proliferation period (Li et al. 2008) and final seed and organ size as well as increases plant biomass. AVP1 encodes a vacuolar pyrophosphatase which functions as a proton pump in the vacuolar membrane and, in transgenic Arabidopsis plants, expression of this gene can increase the vacuolar proton gradient resulting in elevated solute accumulation and water retention (Gaxiola et al. 2001). If this gene is overexpressed in cotton, transgenic plants display improved tolerance to drought and salt stress (Pasapula et al. 2011). The major role of the AtGLU2 gene is nitrogen assimilation in plant roots (Coschigano et al. 1998; Lancien et al. 2002). A positive correlation between nitrogen content and photosynthetic capacity through RuBisCO (ribulose-1, 5-bisphosphate carboxylase/oxygenase) is well-documented in higher plants (Evans 1989). In rice, the multiple gene family $r b c S$ consists of five genes whose expression is enhanced by increased nitrogen (Suzuki et al. 2007; Miyazaki et al. 2013). The relationship between the $r b c S$ and $r b c L$ genes leads to leaf senescence and nitrogen influx (Imai et al. 2008).

The bar gene-based selection system produced numerous herbicide-resistant biotech crops, e.g., oilseed rape (De Block et al. 1989; Kopertekh et al. 2009), lettuce (McCabe et al. 1999), soybean (Zeng et al. 2004), mungbean (Sonia et al. 2007), carrots (Jayaraj et al. 2008), sweet potato (Zang et al. 2009), sugarcane (Joyce et al. 2010), cassava (Koehorst-van Putten et al. 2012), and tomato (Khuong et al. 2013).

The bar gene selection was also successfully used for conifers, Pinus radiate (Charity et al. 2005), orchids (Knapp et al. 2000), and flower species (Kamo and Young 2009; Chen et al. 2010b).

Among the monocotyledonous plants, e.g., wheat (Weeks et al. 1993; Wu et al. 2008), maize (Zhang et al. 1996), barley (Wu et al. (1998), oat (Kuai et al. 2001), Bermuda grass (Hu et al. 2005), tropical maize (Valdez-Ortiz et al. 2007), and ryegrass (Patel et al. 2013) were reported. The rice transformation protocols using Agrobacterium tumefaciens technology were widely established for several genotypes with either hygromycin (Hiei et al. 1994) or phosphinothricin (PPT) (Toki et al. 1992) selection and continue to represent two dominate selection systems currently used for this crop (Bajaj and Mohanty 2005; Chen et al. 2010a; Twyman et al. 2002).

In this study, we used ten different genes of interest as described above, which are involved in abiotic stresses mainly drought tolerance, including the $\mathrm{ABA}$ and nitrogen signaling pathway and plant growth. Our goal was to establish an Agrobacterium-mediated transformation protocol for Curinga, a commercial upland rice variety from Brazil in combination with bar gene selection using a PPT and bialaphos stepwise selection scheme.

\section{Materials and methods}

Plant material

The donor Curinga plants for the mature embryo/seed production were grown in the screen house at temperature 32 $35{ }^{\circ} \mathrm{C} / 20{ }^{\circ} \mathrm{C}$ (day/night) with a $12 / 12$ photoperiod. Surface sterilized mature embryos were cultured scutellum side up for 2 weeks on Chu (Chu 1978) callus induction medium (Table 1). After 15 days, induced embryogenic calli were subcultured to the same medium and cultures proliferated for another 15 days in the same culture conditions at $24-26^{\circ} \mathrm{C}$ in darkness. Well-developed embryogenic calli were subcultured 3 days prior to the transformation experiments to the same Chu callus induction medium supplemented additionally with $100 \mu \mathrm{M}$ acetosyringone and were maintained in darkness at $24-26^{\circ} \mathrm{C}$. For composition of all media used in this study, see Table 1.

PPT and bialaphos tissue sensitivity test

Different concentrations of PPT or bialaphos in Chu medium and MS medium (Murashige and Skoog 1962) were tested for different stages of rice culture development: embryogenic calli proliferation on Chu medium supplemented with 3,5 , and $7 \mathrm{mg} / 1$ and MS medium for the shoots' induction, proliferation, and rooting supplemented with 1,3 and, $5 \mathrm{mg} / \mathrm{l}$. The lethal dose (LD) 50 and 100 were determined for different developmental stages, and those concentrations were used in a stepwise selection scheme for transformation experiments to select transgenic cells and induced shoots allowing them to form roots in the presence of the selection agent.

Constructs, transformation, and plant selection

The binary vector $\mathrm{p} 7 \mathrm{i} 2 \mathrm{xU}$ was used in combination with the following genes of interest: AtNCED3, AtGLU2, Lsi1, LEW2, PLD-alpha, DA1, TOR, AVP1, and two Rubisco genes (provided by Dr. Hermann Schmidt from DNA Cloning Service, Germany) were driven by maize Ubi-1 promoter and selection marker gene. The bar gene was driven by doubled CaMV $35 \mathrm{~S}$ promoter in all constructs (Fig. 1). Ten constructs were individually transferred into A. tumefaciens strain EHA 105 by electroporation (Wen-jun and Forde 1989). 
Table 1 Media used

\begin{tabular}{|c|c|c|}
\hline Medium & Abbreviation & Composition \\
\hline Callus induction & Chu-Ind. & $\begin{array}{l}\text { Chu medium (macro, micro elements, vitamins), } 500 \mathrm{mg} / 1 \mathrm{~L}-\text { proline, } 500 \mathrm{mg} / 1 \mathrm{~L} \text {-glutamine, } \\
300 \mathrm{mg} / 1 \text { casein enzymatic hydrolyzate, } 100 \mathrm{mg} / 1 \mathrm{myo}-\text { inositol, } 30 \mathrm{~g} / 1 \mathrm{maltose}, 2.5 \mathrm{mg} / 1 \text { 2,4-D, } \\
3 \mathrm{~g} / \mathrm{l} \text { gelrite, } \mathrm{pH} 5.8\end{array}$ \\
\hline Pre-culture & $\mathrm{Chu}+\mathrm{AS}$ & as Chu-Ind. plus $100 \mu \mathrm{M}$ acetosyringone, $\mathrm{pH} 5.8$ \\
\hline YEP & & $5 \mathrm{~g} / 1$ yeast extract, $10 \mathrm{~g} / 1$ peptone, $5 \mathrm{~g} / 1 \mathrm{NaCl}, 15 \mathrm{~g} / 1$ bacteriological agar, $\mathrm{pH} 7$ \\
\hline Chu-Infection & Chu-Inf. & $\begin{array}{l}\text { Chu medium (macro, micro elements, vitamins), } 2 \mathrm{mg} / 1 \text { 2, 4-D, } 1 \mathrm{~g} / 1 \text { casamino acids, } 15 \mathrm{~g} / 1 \text { maltose, } \\
15 \mathrm{~g} / 1 \text { glucose, } \mathrm{pH} 5.2\end{array}$ \\
\hline Co-culture & $\mathrm{Chu}+\mathrm{AS}$ & as Chu-Ind. plus $100 \mu \mathrm{M}$ acetosyringone, $\mathrm{pH} 5.8$ \\
\hline Washing & Chu-W & Chu medium (macro, micro elements, vitamins, $500 \mathrm{mg} / \mathrm{l}$ cefotaxime, $\mathrm{pH} 5.8$ \\
\hline Selection & Chu S1, S2 & Chu-Ind. plus3, $5 \mathrm{mg} / \mathrm{l}$ PPT or bialaphos, $250 \mathrm{mg} / \mathrm{l}$ cefotaxime, $\mathrm{pH} 5.8$ \\
\hline Shoots induction & MS Ind. & $\begin{array}{l}\text { MS medium (macro, micro elements, vitamins), } 1 \mathrm{mg} / 1 \mathrm{NAA} 4 \mathrm{mg} / \mathrm{l} \text { kinetin, } 250 \mathrm{mg} / 1 \text { cefotaxime, } \\
3 \mathrm{mg} / \mathrm{l} \text { PPT or bialaphos, pH 5.8, }\end{array}$ \\
\hline Shoots rooting & MS-R & $\begin{array}{l}\text { MS medium (macro, micro elements, vitamins) hormone free, } 250 \mathrm{mg} / 1 \text { cefotaxime, } 5 \mathrm{mg} / 1 \mathrm{PPT} \text { or } \\
\text { bialaphos, } \mathrm{pH} 5.8\end{array}$ \\
\hline
\end{tabular}

A. tumefaciens strain EHA 105 carrying binary vector was cultured on minimum AB medium (Chilton et al. 1974) supplemented with the following antibiotics: $100 \mu \mathrm{g} / \mathrm{ml}$ spectinomycin, $300 \mu \mathrm{g} / \mathrm{ml}$ streptomycin, and $60 \mu \mathrm{g} / \mathrm{ml}$ rifampicin. Plates were cultured at $28{ }^{\circ} \mathrm{C}$ until individual colonies were visible. One colony was used to prepare a yeast extractpeptone (YEP) plate which was subsequently used to prepare YEP liquid culture $24 \mathrm{~h}$ before the transformation experiments. Next morning, Agrobacterium cultures were centrifuged (10 min $4000 \mathrm{rpm}$ at room temperature), and pellets were resuspended with liquid filter-sterilized Chu infection medium supplemented with $15 \mathrm{~g} / 1$ maltose and glucose, $1 \mathrm{~g} / \mathrm{l}$ casamino acid, and $100 \mu \mathrm{M}$ acetosyringone ( $\mathrm{pH}$ 5.2). $\operatorname{Vir} G$ genes were induced at $21{ }^{\circ} \mathrm{C}$ between 1.5 and $3 \mathrm{~h}$. Individual embryogenic rice calli were inoculated with approximately $20 \mu \mathrm{l}$ Agrobacterium suspension, O.D. 0.5 (at room temperature) and after 45-50 min access, Agrobacterium suspension was blotted dry with sterile filter paper.

Cocultivation was carried out in darkness at $21{ }^{\circ} \mathrm{C}$ for 3 days. The infected embryogenic calli after washing with liquid Chu medium contain cefotaxime were transferred directly to Chu selection media supplemented with $3 \mathrm{mg} / \mathrm{l}$ PPT or bialaphos following by transfer to the fresh medium with $5 \mathrm{mg} / \mathrm{l}$ PPT or bialaphos after 15 days. All callus cultures were maintained in darkness at $24-26^{\circ} \mathrm{C}$.
Fig. 1 Schematic representation of the binary vector with AtNCED3 gene

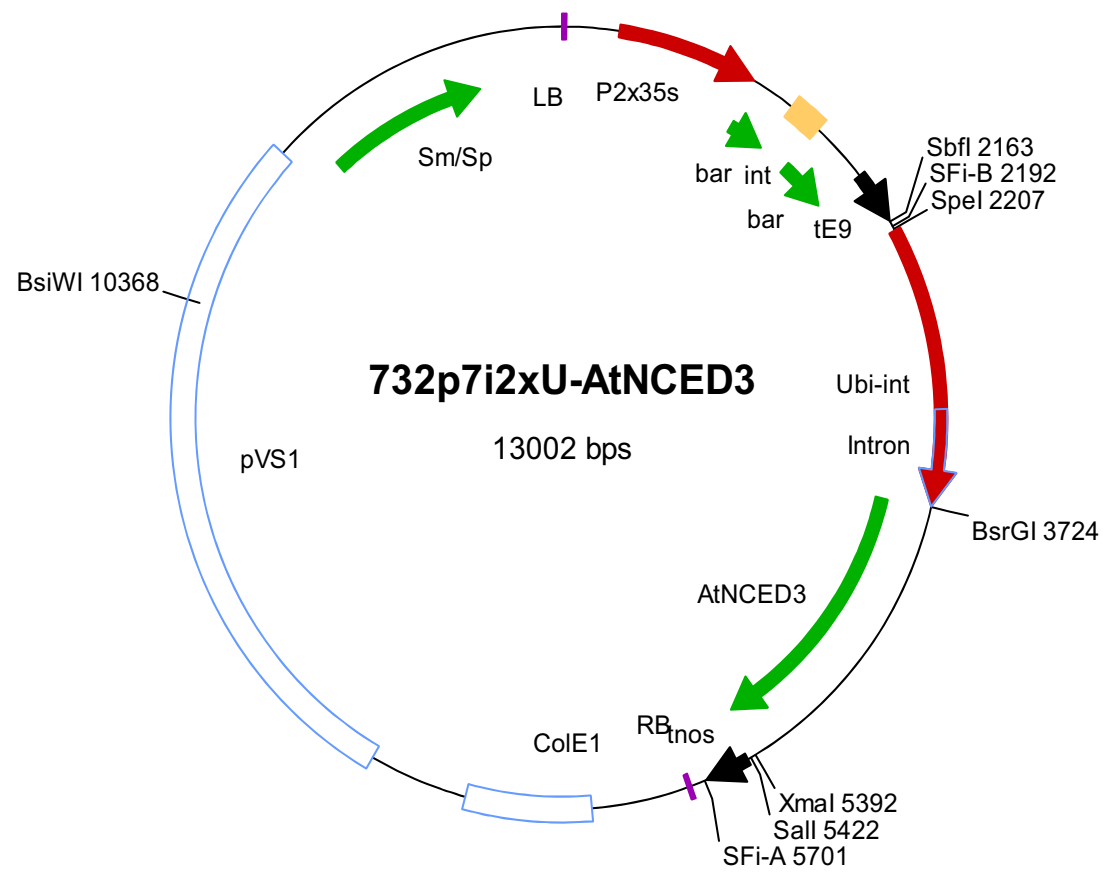


Well-growing calli in the presence of the selection agent were transferred to MS shoots induction medium containing $3 \mathrm{mg} / \mathrm{l} \mathrm{PPT}$ or bialaphos supplemented with $1 \mathrm{mg} / \mathrm{l}$ naphthalene acetic acid (NAA) and $4 \mathrm{mg} / \mathrm{l}$ kinetin. Cultures were gradually moved from darkness into full light conditions with $12 / 12 \mathrm{~h}$ photoperiod and light intensity $1450 \mu \mathrm{mol} \mathrm{m}{ }^{-2} \mathrm{~s}^{-1}$. Green shoots were rooted in the presence of $5 \mathrm{mg} / \mathrm{l} \mathrm{PPT}$ or bialaphos on MS growth hormone free medium.

\section{Molecular analyses}

\section{DNA extraction}

Following growth under hydroponic conditions for 1 week, young leaves were collected for DNA extraction. The extraction was done according to the rice DNA extraction protocol by Dr. Mathias Lorieux, International Center for Tropical Agriculture (CIAT) (personal communication). Accordingly, $450 \mu \mathrm{l}$ of extraction buffer (100 mM Tris-HCl, pH 8.0; $1.4 \mathrm{mM}$ $\mathrm{NaCl} ; 20$ mM EDTA, pH 8.0; $1 \%$ polyethylene glycol, wt $8000 ; 2 \%$ alkyltrimethylammonium bromide, $\geq$ $95 \% ; 0.5 \%$ sodium hydrogensulfite) were added to each tube containing $150 \mathrm{mg}$ of ground leaf tissue and incubated at $74{ }^{\circ} \mathrm{C}$ for $30 \mathrm{~min}$. Then, $480 \mu \mathrm{l}$ of chloroform/isoamyl alcohol (24:1) was added and mixed for $5 \mathrm{~min}$. After centrifugation at room temperature for $30 \mathrm{~min}(4000 \mathrm{rpm})$, the supernatant was transferred to a new tube and precipitated by using $270 \mu \mathrm{l}$ isopropanol for $1 \mathrm{~h}$ at $20^{\circ} \mathrm{C}$. Samples were centrifuged at $10^{\circ} \mathrm{C}$ for $30 \mathrm{~min}$ (4000 rpm), and the pellet was washed with $70 \%$ ethanol and resuspended in nuclease free water. Re-precipitation with ammonium acetate provided good quality DNA suitable for Southern blot analysis.

Polymerase chain reaction analyses

Amplification of the bar gene region by conventional polymerase chain reaction (PCR) was done as an initial screening to select potential transgenic events with the following primers:

\section{Bar-Fw-3 : 5' - GCACGCAACGCCTACGACTGG-3' Bar-Rv-3 : $\mathbf{5}^{\prime}$ - TCAGATCTCGGTGACGGGCAG-3'}

PCR conditions were performed with settings of initial denaturation at $95{ }^{\circ} \mathrm{C}$ for $2 \mathrm{~min}, 35$ cycles each at $94{ }^{\circ} \mathrm{C}$ for $30 \mathrm{~s}, 58{ }^{\circ} \mathrm{C}$ for $30 \mathrm{~s}$, and $72{ }^{\circ} \mathrm{C}$ for $30 \mathrm{~s}$ with final extension at $72{ }^{\circ} \mathrm{C}$ for $5 \mathrm{~min}$. PCR products were checked in $1 \%$ agarose gel.
Southern blot analyses

In order to establish copy number of bar gene and to identify independent transgenic events, $10 \mu \mathrm{g}$ DNA of each PCRpositive plant was digested using either EcoRI or SmaI (5U/ ug DNA). Because these enzymes only cut once into T-DNA without cutting the bar gene, they can be used to determine the copy number of bar gene. Digested DNA was separated in a $0.8 \%$ agarose gel and blotted on a positively charged membrane nylon (Hybond-N+, Nylon Membranes, Positively Charged, GE Healthcare Bio-Sciences Corp). Membranes were hybridized with digoxygenin-labeled PCR probe for bar overnight and then incubated with the alkaline phosphate conjugated anti-digoxygenin antibody. After washing, blocking, and chemiluminescent reaction, the membranes were exposed to X-ray film for a minimum of $4 \mathrm{~h}$.

Synthesis and labeling of probe was done following the instructions specified by the kit (PCR DIG Probe Synthesis Kit instructions, Roche). Primer bar used in PCR was also used to synthesize the bar DIG probe.

Integration of backbone sequences

PCR amplification of backbone regions linked to T-DNA was performed. For each border, three backbone regions were amplified ranging from the nearest region to the border to almost $1000 \mathrm{pb}$ from border (Table 2). PCR conditions were performed with settings of initial denaturation at $95{ }^{\circ} \mathrm{C}$ for $2 \mathrm{~min}, 35$ cycles at $94{ }^{\circ} \mathrm{C}$ for $30 \mathrm{~s}$, annealing temperature (specific to each set of primers) for $30 \mathrm{~s}$, and $72{ }^{\circ} \mathrm{C}$ for $30 \mathrm{sec}$ or $1 \mathrm{~min}$. Final extension was at $72{ }^{\circ} \mathrm{C}$ for $5 \mathrm{~min}$. PCR products were checked in $1.2 \%$ agarose gel.

\section{Chlorophenol red test}

A chlorophenol red assay was used to verify the bar gene activity in selected putative transgenic plants (Wright et al. 2001) and untransformed controls. Leaf segments were placed into individual wells of a multi-well plate containing half concentration of MS medium supplemented with $25 \mathrm{mg} / \mathrm{l}$ chlorophenol red, $3 \mathrm{mg} / \mathrm{l}$ bialaphos, and $8 \mathrm{~g} / \mathrm{l}$ bacto agar, pH 6.2 and were incubated at $26^{\circ} \mathrm{C}$ for $24 \mathrm{~h}$.

\section{PPT leaf painting test}

The T0 plants and untransformed controls grown in the screen house were tested with $2 \%$ aqueous solution of PPT containing $0.1 \%(v / v)$ Tween-20 (Rasco-Gaunt et al. 1999) as well with aqueous solution of $0.1 \%$ Tween-20. Leaf tissue response to PPT presence was scored after 1 week. 
Table 2 Amplification of backbone regions

\begin{tabular}{|c|c|c|}
\hline Primer & Sequence $\left(5^{\prime}-3^{\prime}\right)$ & Distance (bp) outside RB \\
\hline $\mathrm{RB} 17 \mathrm{pb} \mathrm{Rv}$ & ACGCTCTTTTCTCTTAG & 17 \\
\hline T-DNA 141 bp Fw & TAGCGCGCAAACTAGGATAAA & \\
\hline $\mathrm{RB} 101 \mathrm{pb} \mathrm{Rv}$ & GAACCCTGTGGTTGGCAT & 101 \\
\hline T-DNA 141 bp Fw & TAGCGCGCAAACTAGGATAAA & \\
\hline $\mathrm{RB} 867 \mathrm{bp} \mathrm{Rv}$ & GATTAGCAGAGCGAGGTATGTAG & 867 \\
\hline T-DNA 112 bp Fw & CGCGGTGTCATCTATGTTACTA & \\
\hline Primer & Sequence $\left(5^{\prime}-3^{\prime}\right)$ & Distance (bp) outside LB \\
\hline LB $20 \mathrm{pb} \mathrm{Fw}$ & GGGTGCAAAGCGGCAGCGGC & 20 \\
\hline T-DNA 120 bp Rv & ATAACGCTGCGGACATCTAC & \\
\hline LB 97 pb Fw & ACATGGCTCAGTTCTCAATGG & 97 \\
\hline T-DNA 50 bp Rv & TGACCATCATACTCATTGCTGAT & \\
\hline T-DNA 120 bp Rv & ATAACGCTGCGGACATCTAC & 935 \\
\hline LB 935 bp Fw & GATCGACATTGATCTGGCTATCT & \\
\hline
\end{tabular}

\section{Results}

Effect of PPT and bialaphos on rice tissues

Prior to the transformation experiments, we tested untransformed Curinga tissue sensitivity to both selective agents, PPT and bialaphos, in Chu medium for callus proliferation and MS medium for shoots induction and rooting (Fig. 2). Parallel control cultures were carried out on media without selective agents (Fig. 2a-c). Three concentrations of PPT and bialaphos $(1,3$, and $5 \mathrm{mg} / \mathrm{l})$ were tested on callus proliferation in the $\mathrm{Chu}$ medium. The callus cultures were transferred to the fresh medium with increased concentration of PPT or bialaphos every 15 days. A strong tissue necrosis became visible after the second transfer (Fig. 2d). The shoots induction was originally tested with 10 and $20 \mathrm{mg} / 1$ PPT or bialaphos on MS medium. These concentrations were too high for Curinga calli so no shoots formed (Fig. 2e). Consequently, the LD 100 was determined for PPT and bialaphos as $3 \mathrm{mg} / \mathrm{l}$ for shoots induction and $5 \mathrm{mg} / \mathrm{l}$ for roots formation (Fig. 2f).

Transgenic plant selection

A minimum of four transformation experiments were performed with ten constructs where embryogenic calli from approximately 50 mature embryos were induced and subcultured. We selected 302 putative transgenic plants with either mixed selection scheme where both PPT and bialaphos were used or where only one selection agent was used through the entire selection process. Callus selection was done on $\mathrm{Chu}$ medium supplemented with $3 \mathrm{mg} / \mathrm{l}$ PPT or bialaphos. Fifteen days following selection, pressure was increased to $5 \mathrm{mg} / \mathrm{l}$ in the second subculture. We also performed experiments with two calli subcultures with $3 \mathrm{mg} / \mathrm{l}$ PPT, followed by a third one with $5 \mathrm{mg} / \mathrm{l}$ PPT in 15-day intervals.
When we statistically analyzed (chi-square test using SAS version 9.2 on the Linux platform) the number of transgenic plants obtained from these two different selection schemes, the results showed no statistically significant difference between the experiments. Furthermore, there was no statistically significant difference between the experiments carried out with PPT, bialaphos, or with the mix of both selection agents during the entire selection process (data not shown).

When we analyzed the number of calli needed to produce one transgenic plant depending on the construct and selection agent, the results showed significant differences (Table 3 ). The PPT selection worked better with the following constructs p7i2xU-AVP1, AtNCED3, p7i2xU-DA1, and p7i2xU-TOR in difference bialaphos was better for AtGLU2, p7i2xU-Lsi1, p7i2xU-PLD-alpha, and both p7i2xU-Rubisco genes. The mixed selection worked similar to the PPT only for $\mathrm{p} 7 \mathrm{i} 2 \mathrm{xU}$ AVP1 construct. For the shoots induction, we used MS medium supplemented with $3 \mathrm{mg} / \mathrm{l}$ PPT or bialaphos and for rooting the concentration of selection agents was increased to $5 \mathrm{mg} / \mathrm{l}$ (Fig. $3 \mathrm{a}-\mathrm{d})$.

Molecular analyses of transgenic plants

Overall, we analyzed 273 T0 plants using Southern blot analysis of which 134 transgenic events from ten constructs were confirmed while 73 plants carried only a single copy of the transgene (Table 4). The transformation efficiency (TE) for all constructs used represented $49 \%$ when TE was calculated as the number of T0 plants selected in vitro and transgenic plants identified by Southern blot analyses. Overall, 45 events from nine constructs were selected on PPT alone during the entire selection process and 54 events from ten constructs were obtained on bialaphos alone. In contrast, only 24 events were selected with the mixed selection schema. 
Fig. 2 Curinga tissues' sensitivity test. a Callus induction on Chu medium, control. b Shoots induction on MS medium, control. c Callus induction with $3 \mathrm{mg} / \mathrm{l}$ bialaphos. d Shoots induction with $3 \mathrm{mg} / \mathrm{l}$ bialaphos. e Rooting on MS medium, control. f Rooting with $5 \mathrm{mg} / \mathrm{l}$ bialaphos (scale bar in $\mathrm{mm}$ )
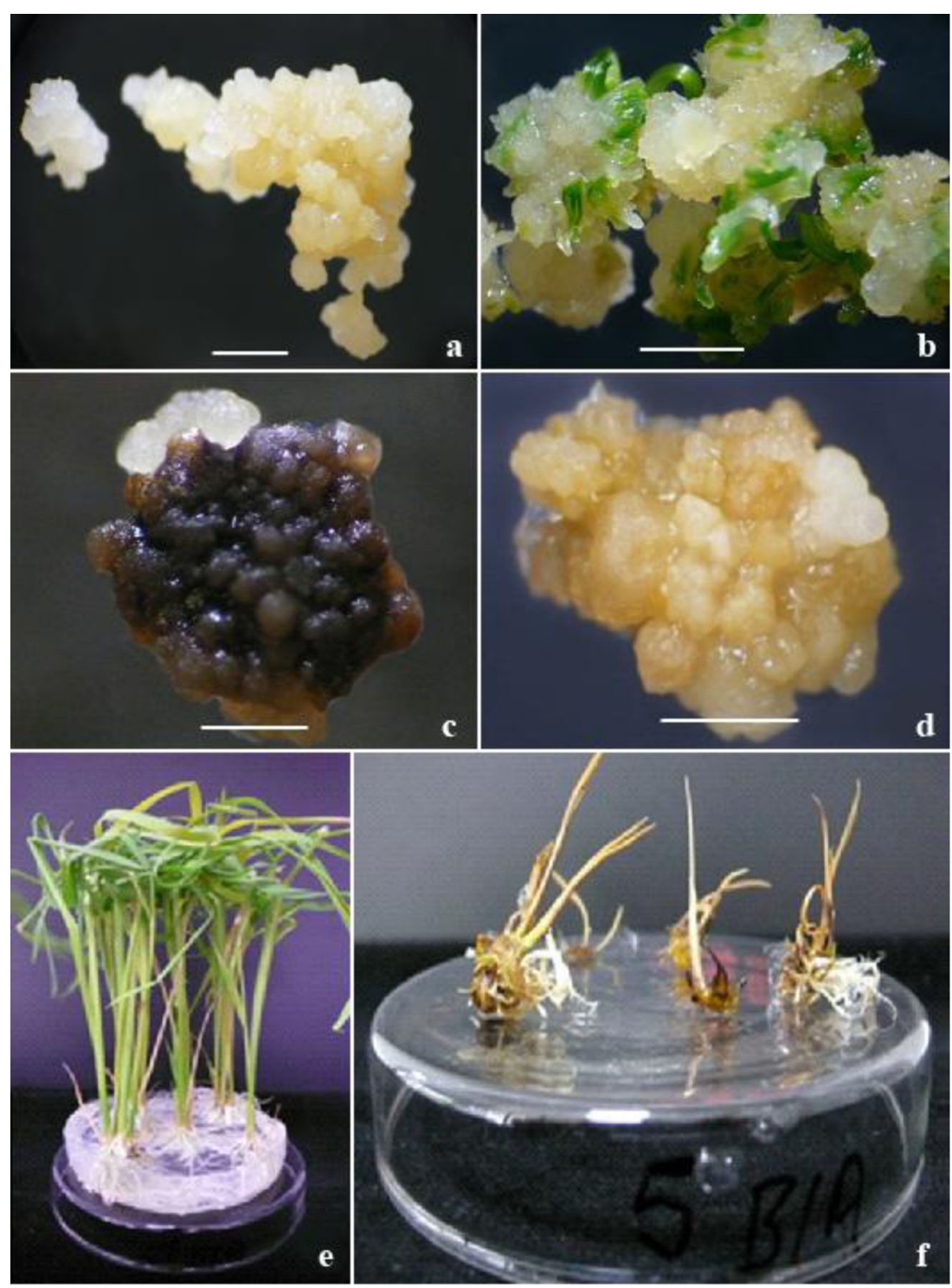

\section{PCR of bar gene}

From 321 Curinga rice plants regenerated and analyzed by PCR, 143 showed amplification of the bar gene (Table 4 and Fig. 4a) and were considered as transgenic or PCR positive. Amplification of a band of $318 \mathrm{bp}$ confirmed the transgenic status of plants. This first screening through PCR allowed plant selection for subsequent molecular characterization through Southern blot.

\section{Southern blot analyses}

Through Southern blot analysis, 134 different transgenic events have been identified. Copies of the bar gene integrated in rice genome ranged from one to several (Table 4 and
Fig. 5). The maximum copy number of transgene integrated in rice plants were five. Of the total events, 77 had one copy of bar gene which represents $57.46 \%$, and 29 events had two copies which represents $21.64 \%$. Our results showed that in total $79.1 \%$ of all transgenic events obtained harbored low copy number of the transgene. Only $16.41 \%$ of events harbored three copies, and $4.47 \%$ events were considered as multi-copy events ( $\geq 4$ bar gene copies).

\section{Backbone regions linked to T-DNA}

Five pairs of primers covering regions outside the T-DNA borders were used in different PCRs to determine if there was integration of backbone sequences. One hundred and one transgenic plants belonging to all constructs and 
Table 3 Number of calli needed to obtain one transgenic plants when PPT (PPT), bialaphos (BIA), or mixture of both selection agents (PPTBIA) have been used

\begin{tabular}{|c|c|c|c|}
\hline Selection agent & Construct & $F^{\mathrm{a}}$ & $\begin{array}{l}\text { Number } \\
\text { of calli }\end{array}$ \\
\hline BIA & $\mathrm{p} 7 \mathrm{i} 2 \mathrm{xU}-A V P 1$ & 0.01603 & 186 \\
\hline PPT & $\mathrm{p} 7 \mathrm{i} 2 \mathrm{xU}-A V P 1$ & 0.03475 & 85 \\
\hline PPT-BIA & p7i $2 x U-A V P 1$ & 0.03333 & 89 \\
\hline BIA & p7i2xU-AtGLU2 & 0.00493 & 607 \\
\hline PPT & $\mathrm{p} 7 \mathrm{i} 2 \mathrm{xU}-A t \mathrm{GLU} 2$ & 0.00402 & 745 \\
\hline BIA & p7i2xU-AtNCED3 & 0.01542 & 193 \\
\hline PPT & p7i2xU-AtNCED3 & 0.02370 & 125 \\
\hline PPT-BIA & p7i2xU-AtNCED3 & 0.00164 & 1829 \\
\hline BIA & p7i2xU-DA1 & 0.00503 & 595 \\
\hline PPT & p7i2xU-DA1 & 0.03659 & 81 \\
\hline PPT-BIA & p7i2xU-DA1 & 0.01316 & 227 \\
\hline BIA & p7i2xU-Lsi1 & 0.02841 & 104 \\
\hline PPT & p7i2xU-Lsi1 & 0.01786 & 167 \\
\hline PPT-BIA & p7i2xU-Lsi1 & 0.01427 & 209 \\
\hline BIA & p7i2xU-PLD-alpha & 0.05556 & 53 \\
\hline PPT & p7i2xU-PLD-alpha & 0.01282 & 233 \\
\hline PPT-BIA & p7i2xU-PLD-alpha & 0.00714 & 418 \\
\hline BIA & p7i2xU-Rubisco 1 & 0.01786 & 167 \\
\hline PPT & p7i2xU-Rubisco 1 & 0.02139 & 139 \\
\hline PPT-BIA & p7i2xU-Rubisco 1 & 0.01205 & 248 \\
\hline BIA & p7i2xU-Rubisco 2 & 0.04545 & 65 \\
\hline PPT & p7i2xU-Rubisco 2 & 0.00778 & 384 \\
\hline PPT & p7i2xU-TOR & 0.04712 & 63 \\
\hline PPT-BIA & p7i2xU-TOR & 0.01613 & 185 \\
\hline
\end{tabular}

${ }^{\text {a }}$ Treatment means were compared using $95 \%$ confidence intervals

representing unique events were analyzed by PCR (Table 5 and Fig. 4b). For each border, three backbone regions were amplified demonstrating varying distances from each border. As shown in Table 5, in the case of the right border (RB), $25.7 \%$ (26) of the total transgenic plants analyzed showed PCR amplification of backbone sequences linked to the RB. In the case of the left border (LB), $35.6 \%$ (36) plants showed amplification of backbone regions linked to the LB. In summary, $40.6 \%$ (41) plants had backbone insertions linked to TDNA (either to RB or LB). Of those 41, less than half had backbone integration from both borders $(48.7 \%)$. From all lines that were analyzed, a total of 25 lines $(24.75 \%)$ contained insertion toward right border and 36 lines $(35.64 \%)$ contained backbone insertion toward left border (data not shown).

\section{Chlorophenol red test}

The color of the medium in this assay changed from purple to yellow indicating that the bar gene activity in transformed rice cells acidified the medium by metabolizing bialaphos. We tested leaf pieces from 45 putative transgenic shoots and untransformed control plants for bar gene expression using the chlorophenol red test (CRT; data not shown). In six cases, the putative transgenic shoots were false negative as determined by the Southern blot analysis, which indicated they were transgenic, carrying the single copy of the transgene. Another plant was identified as negative by CRT; however, it was later identified by Southern blot as transgenic with three copies of the transgene. In contrary, two plants scored positive by CRT but were negative by Southern blot. The results obtained from the CRT and Southern blot showed a $13 \%$ mismatch.

\section{Leaf brush test with PPT}

To evaluate the herbicide resistance level, part of the leaves of transgenic plants and untransformed controls were painted with an aqueous solution of PPT supplemented with TweenOs20. Overall, 23 transgenic plants from eight constructs (p7i2x-AVP1, p7i2x-Lsi1, p7i2x-DA1, p7i2x-Rubiscol, p7i2x-Rubisco2, p7i2x-TOR, p7i2x-AtNCED3, and p7i2xGLU2) showed complete tolerance, i.e., treated leaves stayed green without visible damage, regardless of the transgene copy numbers integrated in the plant genome. However, the leaves of untransformed plants were completely necrotic (data not shown).

T0 plants and T1 seeds

All transgenic events (107 plants) with low copy numbers integrated in rice genome determined by Southern blot analyses were transferred to the screen house (data not shown). Flowering panicles were covered with the pollination bag to prevent cross pollination, and $\mathrm{T} 0$ plants were harvested, additionally dried, and manually trashed. $\mathrm{T} 1$ seeds from individual plant were cleaned and stored at $10{ }^{\circ} \mathrm{C}$ for the following phenotypic experiments.

\section{Discussion}

The bar gene isolated from Streptomyces hygroscopicus encoding the phosphinotricine acetyltransferase (PAT) enzyme which allows resistance to herbicides containing PPT (Thompson et al. 1987, Schomburg and Schomburg 2009) can be used for selection of transgenic plants as initially demonstrated by De Block et al. (1989) for tobacco, potato, and tomato plants. Bialaphos (Ogawa et al. 1973) is a tripeptide antibiotic consisting of PPT, an analog of L-glutamic acid and two L-alanine residues and is produced by fermentation of Streptomyces hydroscopicus (Bayer et al. 1972) by 
Fig. 3 Curinga transgenic tissues. a p7i2xU-Lew2gene callus proliferation with $3 \mathrm{mg} / 1$ bialaphos. b p7i2xU-Rubisco 1 gene shoots induction with $3 \mathrm{mg} / \mathrm{l}$ bialaphos. c p $7 \mathrm{i} 2 \mathrm{xU}-G L U 2$ gene shoots elongation with $3 \mathrm{mg} / 1$ bialaphos. d p7i2xU-AtNCED3 gene rooting with $5 \mathrm{mg} / \mathrm{l}$ bialaphos (scale bar in $\mathrm{mm}$ )
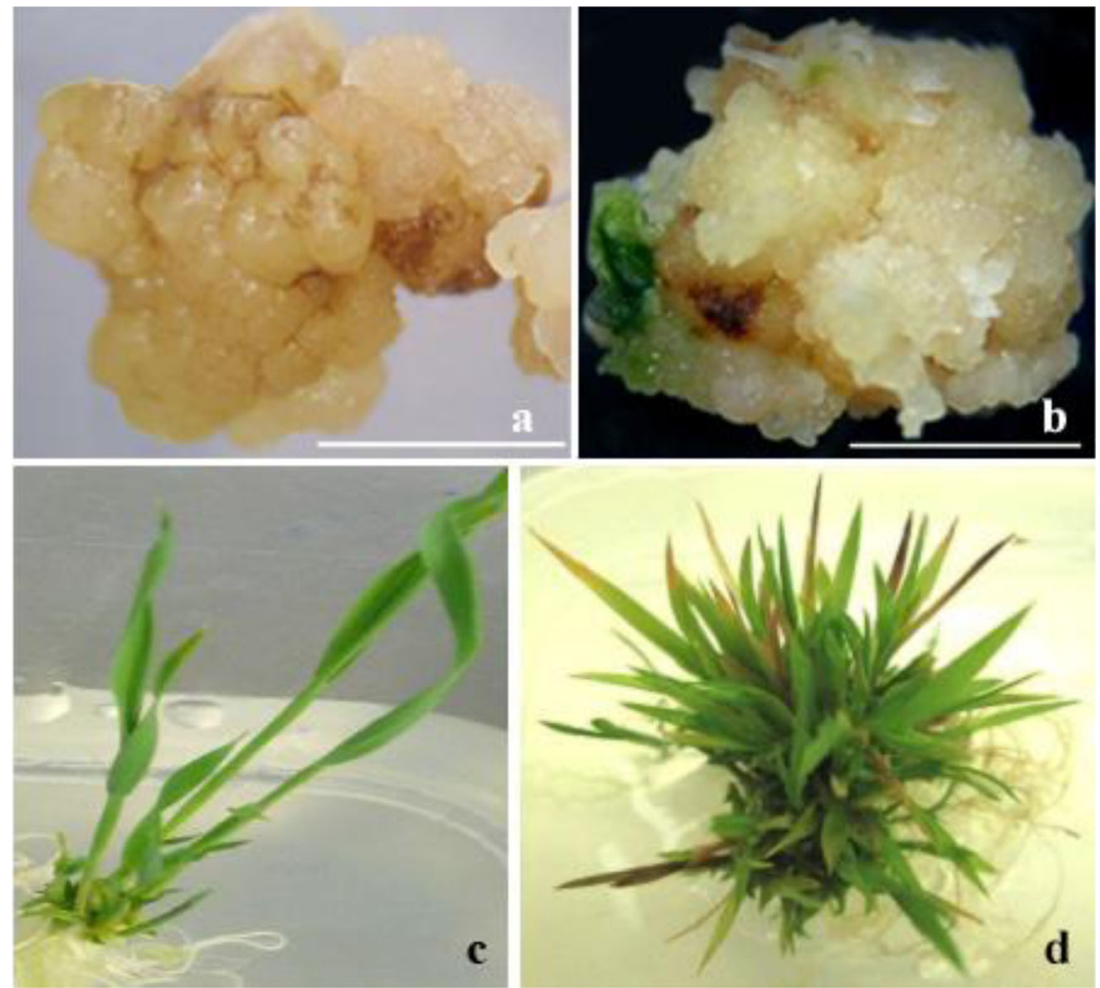

Herbiace ${ }^{\circledR}$, Meiji Seika Ltd. When these residues are removed by peptidases, PPT is able to inhibit glutamine synthetase (GS), the enzyme central to assimilation of ammonium and regulation of nitrogen metabolism (Miflin and Lea 1977). If the GS is inhibited by PPT, accumulation of ammonia results in death of the plant cell (Tachibana et al. 1986). PPT is chemically synthesized by Basta ${ }^{\circledR}$, Hoechst AG, Germany 1975 (currently Sanofi-Aventis, 2004).

The first herbicide-resistant transgenic rice plants with the bar gene were produced by electroporation (Dekeyser et al.
1989; Toki et al. 1992) by polyethylene glycol (PEG)-mediated transformation of rice protoplast (Datta et al. 1990) or by cell suspension cultures transformed via particle bombardment (Cao et al. 1992; Xu et al. 1996).

Agrobacterium-mediated transformation using the bar gene in combination with anti-necrotic treatments was reported for japonica rice R-321 by Enrıquez-Obregon et al. (1999). The following authors used GFP and bar selection with different japonica rice genotypes (Jang et al. 1999; Nakamura et al. 2010) or in combination with transformation histone enhancer

Table 4 Molecular analyses of ten constructs using Southern blot analysis

\begin{tabular}{|c|c|c|c|c|c|c|c|c|c|}
\hline Construct & $\begin{array}{l}\text { No. of } \\
\text { putative } \\
\text { transgenic } \\
\text { plants }\end{array}$ & $\begin{array}{l}\text { No. of plants } \\
\text { analyzed by } \\
\text { Southern blot } \\
\text { analysis }\end{array}$ & $\begin{array}{l}\text { No. of } \\
\text { PCR-positive } \\
\text { plants }\end{array}$ & $\begin{array}{l}\text { No. of } \\
\text { transgenic } \\
\text { events }\end{array}$ & $\begin{array}{l}1 \\
\text { copy }\end{array}$ & $\begin{array}{l}2 \\
\text { copies }\end{array}$ & $\begin{array}{l}3 \\
\text { copies }\end{array}$ & $\begin{array}{l}4 \\
\text { copies }\end{array}$ & $\begin{array}{l}\text { Multi- } \\
\text { copy }\end{array}$ \\
\hline $\mathrm{p} 7 \mathrm{i} 2 \mathrm{x}-A t \mathrm{NCED} 3$ & 46 & 33 & 25 & 20 & 9 & 6 & 3 & 2 & 0 \\
\hline p7i2x-Lsi1 & 63 & 58 & 34 & 29 & 14 & 9 & 6 & 0 & 0 \\
\hline $\mathrm{p} 7 \mathrm{i} 2 \mathrm{x}-D A 1$ & 20 & 18 & 5 & 11 & 8 & 2 & 1 & 0 & 0 \\
\hline $\mathrm{p} 7 \mathrm{i} 2 \mathrm{x}-A V P 1$ & 49 & 38 & 16 & 19 & 11 & 4 & 2 & 1 & 1 \\
\hline p7i2x-Rubisco 1 & 27 & 26 & 12 & 10 & 5 & 1 & 2 & 2 & 0 \\
\hline p7i2x-AtGLU2 & 7 & 5 & 3 & 2 & 1 & 0 & 1 & 0 & 0 \\
\hline $\mathrm{p} 7 \mathrm{i} 2 \mathrm{x}-L E W 2$ & 35 & 32 & 13 & 15 & 8 & 4 & 3 & 0 & 0 \\
\hline p7i2x-PLD-alpha & 22 & 18 & 6 & 9 & 6 & 2 & 1 & 0 & 0 \\
\hline p7i2x-Rubisco2 & 25 & 20 & 7 & 7 & 3 & 1 & 3 & 0 & 0 \\
\hline p7i2x-TOR & 27 & 25 & 22 & 12 & 12 & 0 & 0 & 0 & 0 \\
\hline Total & 321 & 273 & 143 & 134 & 77 & 29 & 22 & 5 & 1 \\
\hline
\end{tabular}




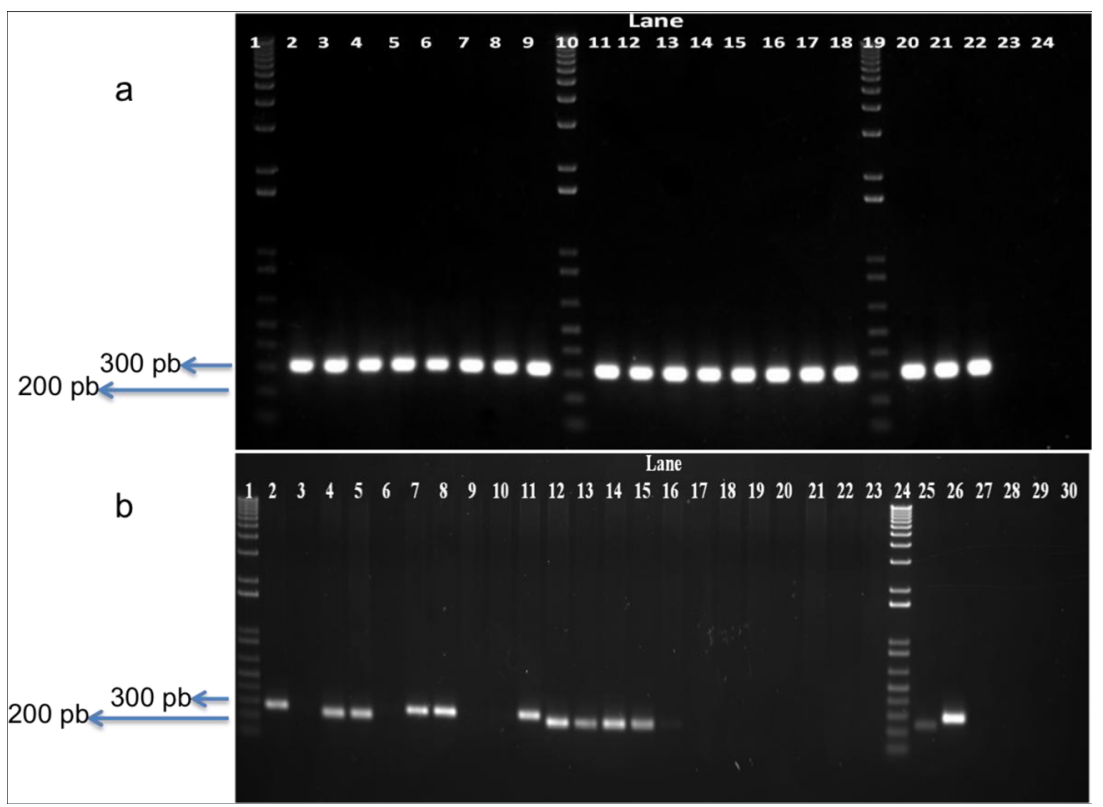

Fig. 4 Molecular analysis through conventional PCR. a PCR amplification of bar gene. Lanes 2-9, 11-18: PCR-positive plants. Lane 20: plasmid transgenic control. Lanes 21 and 22: genomic transgenic controls. Lane 23: not transgenic control. Lane 24: reaction control. Lanes 1, 10, and 19: 1-Kb Plus ladder (Invitrogen). Size of band, 318 bp. b PCR amplification of backbone integration. Lanes 1 and $24: 1-\mathrm{Kb}$ Plus ladder (Invitrogen). Lanes 2-23: transgenic plants under backbone analysis.
Lane 25: plasmid p7i2x-AtNCED3. Lane 26: plasmid p7i2x-PLDalpha. Lanes 27-29: not transgenic controls. Lane 30: reaction control. Size of bands: $279 \mathrm{bp}$ in constructs $\mathrm{p} 7 \mathrm{i} 2 \mathrm{x}-P L D$-alpha and $\mathrm{p} 7 \mathrm{i} 2 \mathrm{x}-$ Rubisco 1 and 242 bp in remaining plasmids. Note the size difference between plants transformed either with constructs $\mathrm{p} 7 \mathrm{i} 2 \mathrm{x}-P L D$-alpha and p7i2x-Rubisco 2 (Lanes 2, 7, 8, and 11) or remaining plasmids (Lanes 4, 5, 12-15)
(Zheng et al. 2009). Recently, Duan et al. (2012) reported a high-throughput protocol for japonica cv. Nipponbare and Wanjing 97 with mannose and bar selection. It is difficult to compare our results with those previously published due to the different rice genotypes used as well as promoters driving the bar gene. Furthermore, we observed big differences among our experiments when we compared the number of calli

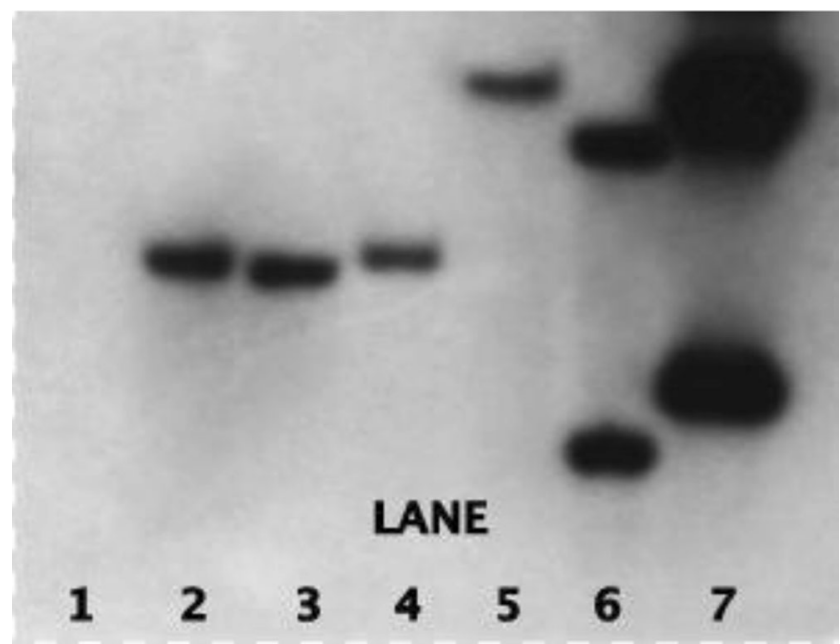

Fig. 5 Southern blot detecting bar gene copy number in transgenic rice plants. Lane 1: not transgenic control. Lanes 2-5: single-copy events. Lane 6: two-copy event. Lane 7: genomic DNA. Lanes 2 and 4, the same transformation event needed for one transgenic plant production if comparing the ten constructs with which we worked.

In our study, the majority ( $73.1 \%)$ of the transgenic events produced using Agrobacterium-mediated transformation at most two copies of the transgene. This confirms that transformation mediated by Agrobacterium favors the regeneration of low copy transgenic plants. Previous studies support this finding, as demonstrated in maize, where Shou et al. (2004) obtained regeneration of $92 \%$ of low copy number events (less than three copies) and sorghum where Zhou et al. (2000) reported $72 \%$ of single-copy events by using Agrobacterium. Dai et al. (2001) also reported the regeneration of low copy events in rice transgenic plants. These reports confirm the central role of Agrobacterium in efficient transformation protocols for agronomically important cereal crops such as rice, wheat, maize, barley, and sorghum (Cheng et al. 2006).

Table 5 PCR analyses of 101 transgenic plants

\begin{tabular}{llll}
\hline $\begin{array}{l}\text { No. of } \\
\text { transgenic } \\
\text { events with } \\
\begin{array}{l}\text { only backbone } \\
\text { integrated } \\
\text { outside RB }\end{array}\end{array}$ & $\begin{array}{l}\text { No. of } \\
\text { transgenic } \\
\text { events with } \\
\text { only backbone } \\
\text { integrated } \\
\text { outside LB }\end{array}$ & $\begin{array}{l}\text { No. of transgenic } \\
\text { events with } \\
\text { integrated } \\
\text { backbone outside }\end{array}$ & $\begin{array}{l}\text { No. of } \\
\text { transgenic } \\
\text { events with no } \\
\text { backbone } \\
\text { sequence } \\
\text { integrated }\end{array}$ \\
\hline 6 & 15 & 20 & 60 \\
\hline
\end{tabular}


A large portion (40.6\%) of rice transgenic plants obtained in our study had backbone sequences linked to T-DNA. Previous studies identified vector backbone sequences linked to T-DNA in a range of species transformed by Agrobacterium including barley (Lange et al. 2006), Arabidopsis (De Buck et al. 2000), tobacco (Kononov et al. 1997 and De Buck et al. 2000), wheat (Wu et al. 2006) and rice (Kim et al. 2003; Afolabi et al. 2004; Kuraya et al. 2004 and Yin and Wang 2000). These reports also show significant ratios of backbone insertions ranking from $20 \%$ (De Buck et al. 2000) to $75 \%$ (Kononov et al. 1997) in transgenic plants not including rice and from $33 \%$ (Yin and Wang 2000) to $92 \%$ (Kuraya et al. 2004 ) in rice transgenic plants. One explanation for the integration of vector backbone appears to be inefficient recognition of the left and right border as initiation and termination sites for T-DNA transfer resulting in read-through at both borders (De Buck et al. 2000). Fang et al. (2000), in study done on rice, identified two types of vector backbone sequence: directly linked to the T-DNA across either LB or RB (type I) and backbone sequence not directly linked to a T-DNA border (type II). In our study, we focused only on type I backbone sequences integration. We found $40.6 \%$ of this type of insertion, and it is only slightly higher compared to what has previously been reported (37.5\%). Moreover, as it was shoved by Zuniga, 2014, CIAT (personal communication), using the chromosome walking approach, the adjacent region of the T-DNA integration in rice can have different configuration closed to RB.

The original chlorophenol red assay described by Kramer et al. (1993) for maize callus selected with PPT was modified for transgenic plants selected with D-mannose for maize and wheat (Wright et al. 2001), for japonica rice (Lucca et al. 2001), for chickpea (Patil et al. 2009), and for transgenic cowpea plants (Bakshi et al. 2012). All of these authors support the high correlation between the CRT and PCR results. Based on our Southern blot results compared to the CRT, we found discrepancies in $13 \%$ of the T0 plants tested. The bar gene expression in $\mathrm{T} 0$ rice plants together with the herbicide resistance of transgenic plants can be tested by the simple leaf painting test, using PPT, bialaphos, or the herbicides Basta (Rathore et al. 1993) and Challenge (Wu et al. 2003). As we found, the results from this assay were highly correlated with the PCR results (Rasco-Gaunt et al. 1999) where all transgenic plants tested positive by PCR with copy number identified by Southern blot analyses. Positive correlation between molecular analyses and bar gene expression resulting herbicide resistance was also described in other crops, for example wheat (Wu et al. 2006), carrot (Jayaraj et al. 2008), or cassava (Koehorst-van Putten et al. 2012).

By producing over hundreds of transgenic events carrying different genes of interest, we created a good basis for the further phenotyping experiments to evaluate the performance for agronomically important traits, as well as we have developed a transformation protocol for an important commercial Brazilian upland rice cultivar with herbicide resistance.

Acknowledgments We would like to acknowledge funding for this work from the EMBRAPA-Monsanto grant, Brasilia. We are also grateful to Mr. G. Delgado for his excellent technical assistance with the rice tissue cultures. Mr. D. Marin for his help with the T0 plants growth and the T1 seeds handling and Mrs. Miriam Duque for the statistical analyses.

Conflict of interest The authors declare that they have no conflict of interest.

Open Access This article is distributed under the terms of the Creative Commons Attribution License which permits any use, distribution, and reproduction in any medium, provided the original author(s) and the source are credited.

\section{References}

Blackwell Publishing, Ltd.

Afolabi A, Worland B, Snape W, Vain P (2004) A large-scale study of rice plants transformed with different T-DNAs provides new insights into locus composition and T-DNA linkage configurations. Theor Appl Genet 109:815-826

Bajaj S, Mohanty A (2005) Recent advances in rice biotechnologytowards genetically superior transgenic rice. Plant Biotechnol J 3: 275-307

Bakshi S, Saha B, Roy NK, Mishra S, Panda K, Sahoo L (2012) Successful recovery of transgenic cowpea (Vigna unguiculata) using the 6-phosphomannose isomerase gene as the selectable marker. Plant Cell Rep 31:1093-1103

Bayer E, Gugel KH, Hägele K, Hagenmaier H, Jessipow S, König WA, Zähner H (1972) Metabolic products of microorganisms. Phosphinothricin and phosphinothricyl-alanyl-analine. Helv Chim Acta 55:224-239

Campbell CA, Myers RJK, Curtin D (1995) Managing nitrogen for sustainable crop production. Fertil Res 42:277-296

Cao J, Duan XL, McElroy D, Wu R (1992) Regeneration of herbicide resistant transgenic rice plants following microprojectile-mediated transformation of suspension culture cells. Plant Cell Rep 11:586591

Chen H, Lin Y, Zhang Q (2010a) Rice. In: Kempker F, Jung C (ed) Genetic modification of plants. Biotechnol Agricult For 64:423-451

Chen Z, Hong X, Zhang H, Wang Y, Li X, Zhu J-K, Gong Z (2005) Disruption of the cellulose synthase gene, AtCesA8/IRX1, enhances drought and osmotic stress tolerance in Arabidopsis. Plant J 43:273283

Chen Y-T, Fang Q-S, Chiang C-H, Yeh S-D, Wu H-W, Yu T-A (2010b) Transgenic Eustoma grandiflorum expressing the bar geneare resistant to the herbicide Basta ${ }^{\circledR}$. Plant Cell Rep 102:347-356

Cheng M, Lowe B, Spencer M, Ye X, Armstrong C (2006) Invited review: factors influencing Agrobacterium-mediated transformation of monocotyledonous species. In Vitro Cell Dev Biol Plant 40:3145

Chu C-C (1978) The N6 medium and its application to another culture of cereal crops. Proc Symp Plant Tissue Culture, Science Press, Peking, pp. 43-50 
Charity JA, Holland L, Grace J, Walter C (2005) Consistent and stable expression of the $n p t \mathrm{II}$, uidA and bar genes in transgenic Pinus radiata after Agrobacterium tumefaciens-mediated transformation using nurse cultures. Plant Cell Rep 23: 606-616

Chilton M-D, Currier T, Farrand S, Bendish A, Gordon M, Nester E (1974) Agrobacterium tumefaciens DNA and PS bacteriophage DNA not detected in crown gall tumors. Proc Natl Acad Sci U S A 71:3672-3676

Coschigano KT, Melo-Oliveira R, Lim J, Coruzzi GM (1998) New Arabidopsis $g l s$ mutants and distinct Fd-GOGAT Genes: implications for photorespiration and primary nitrogen assimilation. Plant Cell 10:741-752

Dai S, Zheng P, Marmey P, Zhang S, Tian W, Chen S, Beachy RN, Fauquet C (2001) Comparative analysis of transgenic rice plants obtained by Agrobacterium-mediated transformation and particle bombardment. Mol Breed 7:25-33

Deikman J, Petracek M, Heard JE (2011) Drought tolerance through biotechnology: improving translation from the laboratory to farmers' fields. Curr Opin Biotechnol 23:1-8

Datta SK, Peterhans A, Datta K, Potrykus I (1990) Genetically engineered fertile indica-rice recovered from protoplasts. Bio/ Technology 8:736-740

De Block M, De Brouwer D, Tenning T (1989) Transformation of Brassica napus and Brassica oleracea using Agrobacterium tumefaciens and the expression of the bar and neo genes in the transgenic plants. Plant Physiol 9:694-701

De Buck S, De Wilde C, Van Montagu M, Depicker A (2000) T-DNA vector backbone sequences are frequently integrated into the genome of transgenic plants obtained by Agrobacterium-mediated transformation. Mol Breed 6:459-468

Dekeyser R, Claes B, Marichal M, Van Montagu M, Caplan A (1989) Evaluation of selectable markers for rice transformation. Plant Physiol 90:217-223

Deprost D, Yao L, Sormani R, Moreau M, Leterreux G, Nicolai M, Bedu M, Robaglia C, Meyer C (2007) The Arabidopsis TOR kinase links plant growth, yield, stress resistance and mRNA translation. EMBO Rep 8:864-870

Duan Y, Zhai Ch H, Li J, Mei W, Gui H, Ni D, Song F, Li L, Zhang W, Yang J (2012) An efficient and high-throughput protocol for Agrobacterium-mediated transformation based on phosphomannose isomerase positive selection in Japonica rice (Oryza sativa L.). Plant Cell Rep 31:1611-1624

Enrıquez-Obregon GA, Prieto-Samsonov DL, de la Riva GA, Perez M, Selman-Housein G, Vazquez-Padron RI (1999) Agrobacterium-mediated Japonica rice transformation: a procedure assisted by an antinecrotic treatment. Plant Cell Tissue Org Cult 59:159-168

Evans R (1989) Photosynthesis and nitrogen relationships in leaves of C3 plants. Ocecologia 78:9-19

Fageria NK (2002) Nutrient management for improving upland rice productivity and sustainability. Communication in Soil Science and Plant Analyses 32:26603-2629

Fageria NK (2009) The use of nutrients in crop plants. CRC Press, New York

Fageria NK (2010) Optimal nitrogen fertilization for upland rice. World Congress of Soil Solutions for a Changing World. 1-6 August, 2010, Brisbane, Australia

Fang J, Zhai WX, Wang WM, Zhu LH (2000) Amplification and analysis of T-DNA flanking sequences in transgenic rice lines. Rice Genet Newsl 17:112-114

FAO (2013) www.fao.org

FAOSTAT (2012) The Statistics Division of the FAO, available at: http:// faostat.fao.org

Gaudin ACM, Henry A, Sparks AH, Slamet-Loedin IH (2013) Taking transgenic rice drought screening to the field. J Exp Bot 64:109-118
Gaxiola RA, Li J, Undurraga S, Dang LM, Allen GJ, Alper SL, Fink GR (2001) Drought- and salt-tolerant plants result from overexpression of the AVP1 H1-pump. Proc Natl Acad Sci U S A 98:11444-11449

Hadiarto T, Tran L-S P (2011) Progress studies of drought-responsive genes in rice. Plant Cell Rep 30:297-310

Hiei Y, Ohta S, Komari T, Kumashiro T (1994a) Efficient transformation of rice (Oryza sativa L.) mediated by Agrobacterium and sequence analysis of the boundaries of the T-DNA. Plant J 6:271-282

$\mathrm{Hu}$ F, Zhang L, Wang X, Ding J, Dianxing, Wu D (2005) Agrobacterium-mediated transformed transgenic triploid bermudagrass (Cynodon dactylon $\times C$. transvaalensis) plants are highly resistant to the glufosinate herbicide Liberty. Plant Cell Tissue Org Cult 83:13-19

Imai K, Suzuki Y, Mae T, Makino A (2008) Changes in the synthesis of Rubisco in rice leaves in relation to senescence and $\mathrm{N}$ influx. Ann Bot 101:135-144

Iuchi S, Kobayashi M, Ti T, Naramoto M, Seki M, Kato T, Tabata S, Kakubari Y, Yamaguchi-Shinozaki K, Shinozaki K (2001) Regulation of drought tolerance by gene manipulation of 9-cisepoxycarotenoid dioxygenase, a key enzyme in abscisic acid biosynthesis in Arabidopsis. Plant J 27:325-333

Jang I-C, Nahm BH, Kim J-K (1999) Subcellular targeting of green fluorescent protein to plastids in transgenic rice plants provides a high-level expression system. Mol Breed 5:453-46

Jayaraj J, Devlin JR, Punj Z (2008) Metabolic engineering of novel ketocarotenoid production in carrot plants. Transgenic Res 17: 489-501

Jeong JS, Kim YS, Redillas MCFR, Jang G, Jung H, Bang SW, Choi YD, Ha SH, Rousseau C, Kim JK (2013) OsNAC5 overexpression enlarges root diameter in rice plants leading to enhanced drought tolerance and increased grain yield in the field. Plant Biotechnol J $11: 101-114$

Joyce P, Kuwahata M, Turner N, Lakshmanan P (2010) Selection system and co-cultivation medium are important determinants of Agrobacterium-mediated transformation of sugarcane. Plant Cell Rep 29:173-183

Kamo K, Young HY (2009) Long-term gus expression from Gladiolus callus lines containing either a bar-uid $\mathrm{A}$ fusion gene or bar and uidA delivered on separate plasmids. Plant Cell Tiss Organ Cult 98:263272

Kim S, Lee J, Jun S, Park S, Kang H, Kwon S, An G (2003) Transgene structures in T-DNA-inserted rice plants. Plant Mol Biol 52:761773

Knapp EJ, Kauch AP, Chandlee JM (2000) Transformation of three genera of orchid using the bar gene as a selection marker. Plant Cell Rep 19:893-898

Khuong TTH, Crete P, Robaglia C, Caffarri S (2013) Optimisation of tomato Micro-tom regeneration and selection on glufosinate/Basta and dependency of gene silencing on transgene copy number. Plant Cell Rep 32:1441-145

Kopertekh L, Broer I, Schiemann J (2009) Developmentally regulated site-specific marker gene excision in transgenic B. napus plants. Plant Cell Rep 28:1075-1083

Koehorst-van Putten HJJ, Sudarmonowati E, Herman M, Pereira-Bertram IJ, Wolters AMA, Meima H, de Vetten N, Raemakers CJJM, Visser RGF (2012) Field testing and exploitation of genetically modified cassava with low-amylose or amylose-free starch in Indonesia. Transgenic Res 21:39-5

Kononov M, Bassuner B, Gelvin S (1997) Integration of T-DNA binary vector backbone sequences into tobacco genome: evidence for multiplex complex patterns of integration. Plant $\mathrm{J}$ 11:945-957

Kramer C, DiMaio J, Carswell GK, Shilito R (1993) Selection of transformed protoplast-derived Zea mays colonies with phosphinothricin and a novel assay using the $\mathrm{pH}$ indicator. Planta 190:454-458 
Kuai B, Perret S, Wan SM, Dalton SJ, Bettany AJE, Morris P (2001) Transformation of oat and inheritance of bar gene expression. Plant Cell Tissue Org Cult 66:79-88

Kuraya Y, Ohta S, Fukuda M, Hiei Y, Murai N, Hamada K, Ueki J, Imaseki H, Komari T (2004) Suppression of transfer of non-T-DNA 'vector backbone' sequences by multiple left border repeats in vectors for transformation of higher plants mediated by Agrobacterium tumefaciens. Mol Breed 14:309-320

Lancien M, Martin M, Hsieh MH et al (2002) Arabidopsis glt1-T mutant defines a role for NADH-GOGAT in the non-photorespiratory ammonium assimilatory pathway. Plant J 29:347-358

Lange M, Vincze E, Møller M, Holm P (2006) Molecular analysis of transgene and vector backbone integration into the barley genome following Agrobacterium-mediated transformation. Plant Cell Rep $25: 815-820$

Lawlor DW (2013) Genetic engineering to improve plant performance under drought: physiological evaluation of achievements, limitations, and possibilities. J Exp Bot 64:83-108

Li Y, Zheng L, Corke F, Smith C, Bevan MW (2008) Control of final seed and organ size by the DAI gene family in Arabidopsis thaliana. Genes Dev 22:1331-1336

Lucca P, Ye X, Potrykus I (2001) Effective selection and regeneration of transgenic rice plants with mannose as selective agent. Mol Breed 7: 43-49

Ma JM, Tamai K, Yamaji N, Mitani N, Konishi S, Katsuhara M, Ishiguro M, Murata Y, Yano M (2006) A silicon transporter in rice. Nature 440:688-691

McCabe MS, Schepers F, van der Arend A, Mohapatra U, de Laat AMM, Power JB, Davey MR (1999) Increased stable inheritance of herbicide resistance in transgenic lettuce carrying a petE promoter-bar gene compared with a CaMV 35S-bar gene. Theor Appl Genet 99:587-592

Menand B, Desnos T, Nussaume L, Berger F, Bouchez D, Meyer C, Robaglia C (2002) Expression and disruption of the Arabidopsis TOR (target of rapamycin) gene. Proc Natl Acad Sci U S A 99: 6422-6427

Miflin BJ, Lea PJ (1977) Amino acid metabolism. Annu Rev Plant Physiol 28:299-329

Mishra G, Zhang W, Deng F, Zhao J, Wang X (2006) A bifurcating pathway directs abscisic acid effects on stomatal closure and opening in Arabidopsis. Science 322:264-266

Miyazaki N, Ueno O, Saitou K (2013) Effects of nitrogen on the expression of ribulose-1,5-bisphosphate carboxylase/oxygenase small subunit multigene family members in Rice (Oryza sativa L.). Plant Prod Sci $16: 37-40$

Murashige T, Skoog F (1962) A revised medium for rapid growth and bioassays with tobacco tissue cultures. Physiol Plant 15:47-497

Nakamura S, Mano S, Tanaka Y, Ohnishi M, Nakamori C, Araki M, Niwa T, Nishimura M, Kaminaka H, Nakagawa T, Sato Y, Ishiguro S (2010) Gateway binary vectors with the Bialaphos resistance gene, bar, as a selection marker for plant transformation. Biosci Biotechnol Biochem 74:1315-1319

Ogawa Y, Tsuruoka T, Inoue T, Niida S (1973) Studies on a new antibiotic SF-1293. II. Chemical structure of antibiotic SF-1293. Sci Rep Meiji Seika Kaisha 13:42-48

Pasapula V, Shen G, Kuppu S, Paez-Valencia J, Mendoza M, Hou P, Chen J, Qiu X, Zhu L, Zhang X, Auld D, Blumwald E, Zhang H, Gaxiola R, Payton P (2011) Expression of an Arabidopsis vacuolar H+ -pyrophosphatase gene (AVP1) in cotton improves drought- and salt tolerance and increases fiber yield in the field conditions. Plant Biotechnol J 9:88-99

Patil G, Deokar A, Jain PK, Thengane RJ, Srinivasan R (2009) Development of a phosphomannose isomerase-based Agrobacterium-mediated transformation system for chickpea (Cicer arietinum L.). Plant Cell Rep 28: 1669-1676

Patel M, Dewey RE, Qu R (2013) Enhancing Agrobacterium tumefaciens-mediated transformation efficiency of perennial ryegrass and rice using heat and high maltose treatments during bacterial infection. Plant Cell Tiss Org Cult 114:19-29

Rasco-Gaunt S, Riley A, Lazzeri P, Barcelo P (1999) A facile method for screening for phosphinothricin (PPT) resistant transgenic wheats. Mol Breed 5:255-262

Rathore KS, Chowdhury VK, Hodges TK (1993) Use of bar as a selectable marker gene and for the production of herbicide-resistant rice plants from protoplasts. Plant Mol Biol 21:871-884

Schomburg D, Schomburg I (2009) Springer handbook of enzymes. Supplement Volume S2. Springer, Berlin, Heidelberg, New York

Serraj J, Bennett J, Hardy B (2008) Drought frontiers in rice: crop improvement for increased rain fed production. IRRI, $400 \mathrm{p}$. World Scientific Publishing, Los Banos, Philippines

Shinozaki K, Yamaguchi-Shinozaki K (2007) Gene networks involved in drought stress response and tolerance. J Exp Bot 58:221-227

Shou H, Frame B, Whitham S, Wang K (2004) Assessment of transgenic maize events produced by particle bombardment or Agrobacteriummediated transformation. Mol Breed 13:201-208

Sonia, Saini R, Singh RP, Jaiwal PK (2007) Agrobacterium tumefaciens mediated transfer of Phaseolus vulgaris $\alpha$-amylase inhibitor-1 gene into mungbean Vigna radiate (L.)Wilczek using bar as selectable marker. Plant Cell Rep 26:187-198

Suzuki Y, Ohkubo M, Hatakeyama H, Ohashi K, Yoshizawa R, Kojima S, Hayakawa T, Yamaya T, Mae T, Makino A (2007) Increased Rubisco content in transgenic rice transformed with the 'Sense' $r b c S$ gene. Plant Cell Physiol 48:623-637

Tachibana K, Watanaba T, Seikizawa Y, Takematsu T (1986) Accumulation of ammonia in plants treated with bialaphos. J Pestic Sci 11:33-37

Taylor N (2008) Cellulose biosynthesis and deposition in higher plants. New Phytol 278:239-252

Thompson CJ, Movva NR, Tizard R, Crameri R, Davies JE, Lauwereys M, Botterman J (1987) Characterization of the herbicide-resistance gene bar from Streptomyces hygroscopicus. EMBO J 6:2519-2523

Toki S, Takamatsu S, Nojiri C, Ooba S, Anzai H, Iwata M, Christensen AH, Quail PH, Uchimiya H (1992) Expression of a maize ubiquitin gene promoter-bar chimeric gene in transgenic rice plants. Plant Physiol 100:1503-1507

Twyman RM, Stoger E, Kohli A, Capell T, Christou P (2002) Selectable and screenable markers for rice transformation. In: Jackson JF, Linskens HF, Inman RB (eds) Molecular methods of plant analysis. Testing for genetic manipulation in plants, vol 22. Springer, Berlin, Heidelberg

Valdez-Ortiz A, Medina-Godoy S, Valverde ME, Paredes-López O (2007) A transgenic tropical maize line generated by the direct transformation of the embryo-scutellum by A. tumefaciens. Plant Cell Tissue Org Cult 91:201-214

Umezawa T, Fujita M, Fujita Y, Yamaguchi-Shinozaki K, Shinozaki K (2006) Engineering drought tolerance in plants: discovering and tailoring genes unlock the future. Curr Opin Biotechnol 17:113-122

Uraji M, Katagiri T, Okuma E, Ye W, Hossain MA, Masuda C, Miura A, Nakamura Y, Mori IC, Shinozaki K, Murata Y (2012) Cooperative function of $P L D a$ and $P L D a 1$ in abscisic acid induced stomatal closure in Arabidopsis. Plant Physiol 199:450-460

Weeks JT, Anderson OD, Blechl A (1993) Rapid production of multiple independent lines of fertile transgenic wheat (Triticum aestivum L.). Plant Physiol 102:1077-1084

Wen-jun S, Forde BG (1989) Efficient transformation of Agrobactenum spp. by high voltage electroporation. Nucleic Acids Res 17:8383

Wright M, Dawson J, Dunder E, Suttie J, Reed J, Kramer C, Chang Y, Novitzky R, Wang H, Artim-Moore L (2001) Efficient biolistic transformation of maize (Zea mays L.) and wheat (Triticum aestivum L.) using the phosphomannose isomerase gene, pmi, as the selectable marker. Plant Cell Rep 20:429-436

Wu H, McCormac AC, Elliott MC, Chen D-F (1998) Agrobacteriummediated stable transformation of cell suspension cultures of barley (Hordeum vulgare). Plant Cell Tissue Org Cult 54:161-171 
Wu H, Doherty A, Jones HD (2008) Efficient and rapid Agrobacteriummediated genetic transformation of durum wheat (Triticum turgidum L. var. durum) using additional virulence genes. Transgenic Res 17: 425-436

Wu H, Sparks CA, Jones HD (2006) Characterization of T-DNA loci and vector backbone sequences in transgenic wheat produced by Agrobacterium-mediated transformation. Mol Breeding 18:195208

Wu H, Sparks CA, Amoah B, Jones HD (2003) Factors influencingsuccesful Agrobacterium-mediated genetic transformation of wheat. Plant Cell Rep 21:659-668

Xu D, Duan X, Wang B, Hong B, Ho T-HD, Wu R (1996) Expression of a late embryogenesis abundant protein gene, HVA1, from barley confers tolerance to water deficit and salt stress in transgenic rice. Plant Physiol 110:249-257

Yamaji N, Ma JF (2007) Spatial distribution and temporal variation of the rice silicon transporter Lsi1. Plant Physiol 143:1306-1313

Yang S, Vanderbeld B, Wan J, Huang Y (2010) Narrowing down the targets: towards successful genetic engineering of drought-tolerance crops. Mol Plant 3:469-490
Yin Z, Wang G (2000) Evidence of multiple complex patterns of T-DNA integration into the rice genome. TAG 100:461-470

Zang N, Zhai H, Gao S, Chen W, He S, Liu Q (2009) Efficient production of transgenic plants using bar gene for herbicide resistance in sweetpotato. Sci Horticult 122:649-653

Zeng P, Vadnais DA, Zhang Z, Polacco JC (2004) Refined glufosinate selection in Agrobacterium mediated transformation of soybean [Glycine $\max (\mathrm{L}$.) Merrill]. Plant Cell Rep $22: 478-472$

Zhang S, Warkentin D, Sun B, Zhong H, Sticklen M (1996) Variation in the inheritance of expression among subclones for unselected (uidA) and selection (bar) transgenes in maize (Zea mays L.). Theor Appl Gen 92:752-761

Zheng Y, He X-W, Ying Y-H, Lu J-F, Gelvin SB, Shou H-X (2009) Expression of the Arabidopsis thaliana Histone gene AtHTA1 enhances rice transformation efficiency. Mol Plant 2:832-837

Zhou Z, Cai T, Tagliani L, Miller M, Wang N, Pang H, Rudert M, Schroeder S, Hondred D, Seltzer J, Pierce D (2000) Agrobacterium-mediated sorghum transformation. Plant Mol Biol 44:789-798 